\title{
Endometrial Adenocarcinoma With Pulmonary Recurrence
}

\author{
Manoj P Rai, ${ }^{1}$ Mandeep Singh Randhawa, ${ }^{2}$ Divyesh Reddy Nemakayala, ${ }^{1}$ \\ Edwin B Marinas ${ }^{3}$
}

'Internal Medicine, Michigan State University / Sparrow Hospital, Lansing, Michigan, United States of America ${ }^{2}$ Department of Cardiology, Michigan State University/ Sparrow Hospital, Lansing, Michigan, USA

${ }^{3}$ Department of Pathology, Sparrow Health System, Lansing, Michigan, USA

\section{Correspondence to}

Dr Manoj P Rai,

manoj.rai@hc.msu.edu

MSR and DRN contributed equally.

Accepted 22 December 2017 CrossMark

\section{To cite: Rai MP,} Randhawa MS,

Nemakayala DR, et al. BMJ Case Rep Published Online First: [please include Day Month Year]. doi:10.1136/ bcr-2017-223015

\section{DESCRIPTION}

We present the case of an 83-year-old woman with a history of grade 1 stage IB endometrial cancer (endometrial adenocarcinoma) (figure 1) involving the lower uterine segment. She underwent robotic hysterectomy with right salpingo-oophorectomy followed by brachytherapy. A year and a half later, she presented with difficulty in breathing. A chest X-ray showed $8 \mathrm{~mm}$ nodular density in the right lower lobe. The above finding was confirmed with CT. Given the concern for a malignant lesion, positron emission tomography/CT scan was performed, which revealed two metabolically active lung nodules, measuring $1.2 \mathrm{~cm}$ in the right middle lobe and other in the right lower lobe measuring $1.2 \mathrm{~cm}$ (figure 2). Video-assisted thoracoscopic wedge resection of the right lower lobe lung nodule

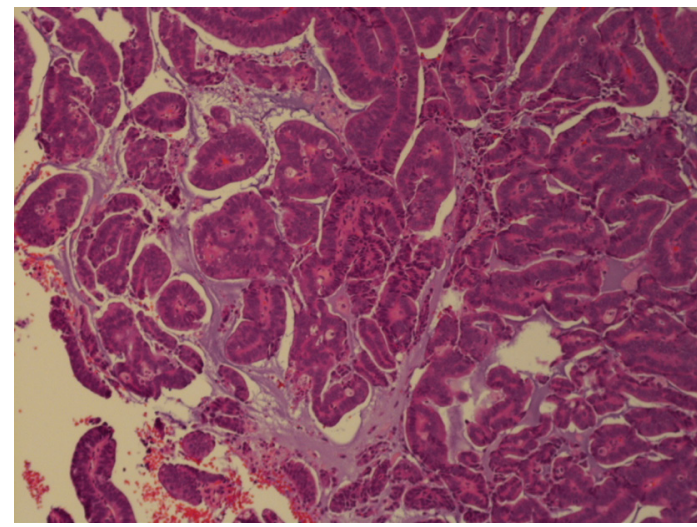

Figure 1 Histopathology showing primary endometrial adenocarcinoma at the time of its diagnosis.

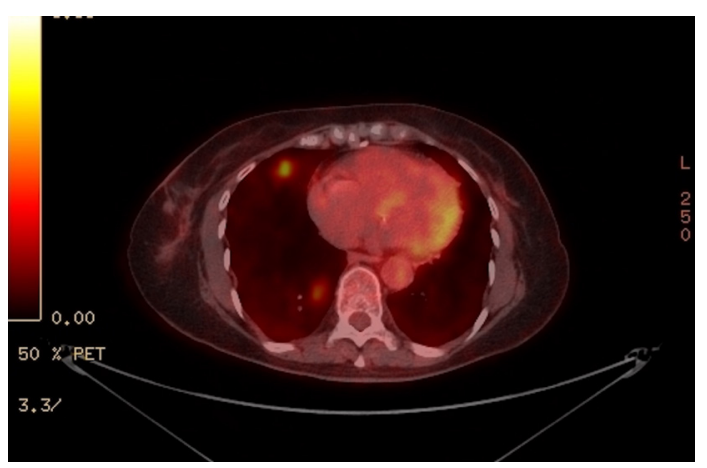

Figure 2 Positron emission tomography/CT showing two metabolically active lung nodules, measuring $1.2 \mathrm{~cm}$ in the right middle lobe and other in the right lower lobe measuring $1.2 \mathrm{~cm}$.

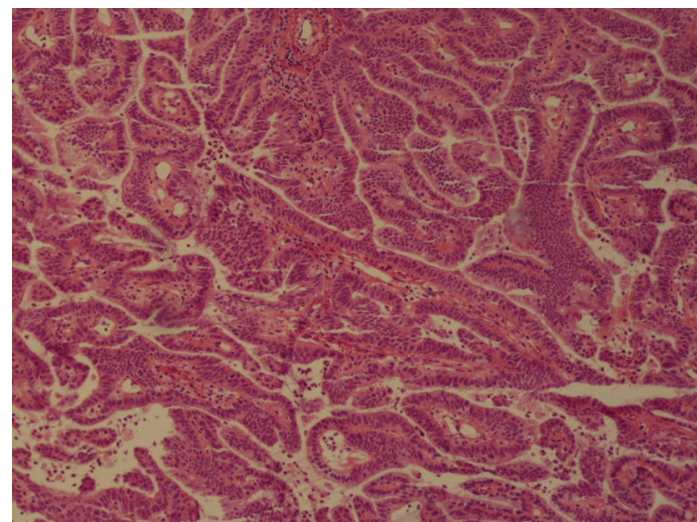

Figure 3 Frozen section showing papillary adenocarcinoma.

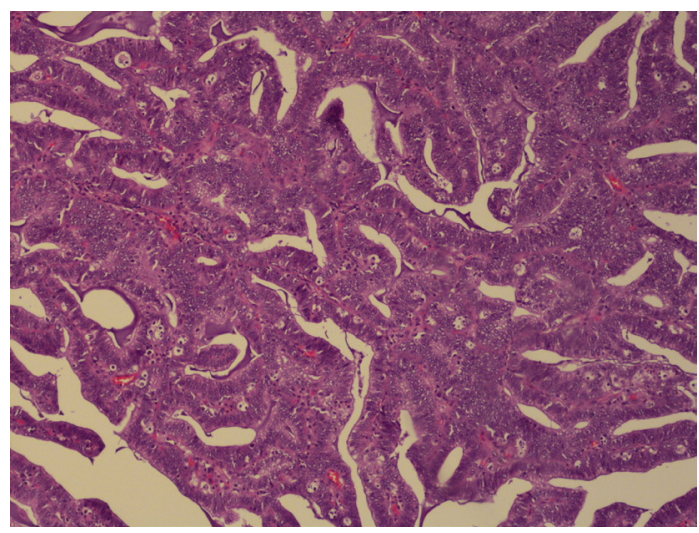

Figure 4 Final pathology showing metastatic endometrial carcinoma in the lung.

was performed. The frozen section and histopathology revealed papillary adenocarcinoma (figures 3 and 4); nuclear staining was positive for oestrogen receptors and negative for thyroid transcription factor-1 (figure 5). Thus, primary lung adenocarcinoma was ruled out and diagnosis of metastatic endometrial carcinoma was established. She was then started on systemic chemotherapy with carboplatin and paclitaxel. The incidence of lung metastasis in patients with endometrial cancer is $2.3-4.6 \% .{ }^{1}$ Patients with stage IVB endometrial carcinoma and deep myometrial invasion are at increased risk for lung metastasis. ${ }^{2}$ The risk factor associated with lung metastasis in our patient was the deep myometrial invasion. ${ }^{3}$ Surgical resection followed by systemic chemotherapy is the standard of care. Overall survival in patients with 


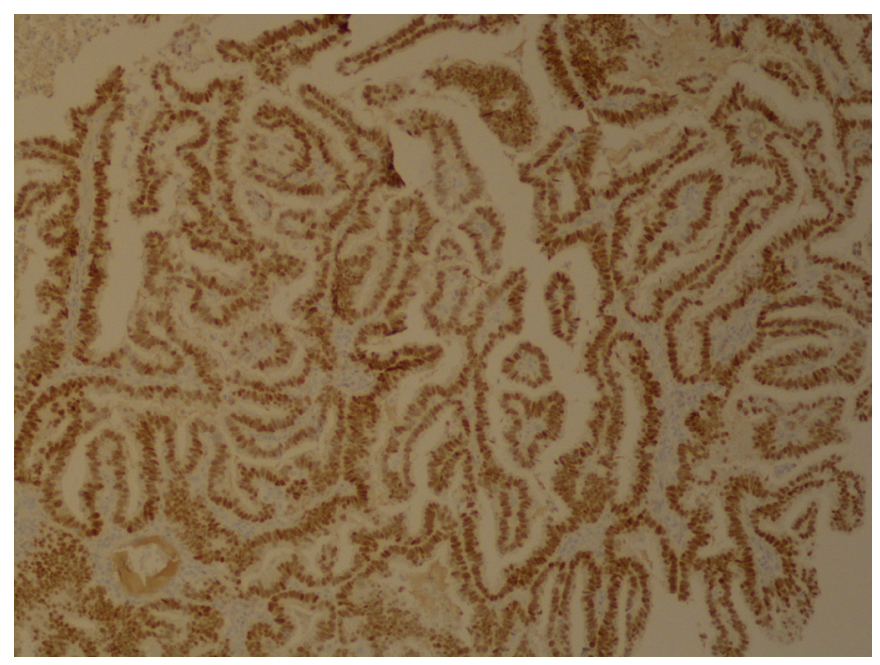

Figure 5 Slide shows positive nuclear staining for oestrogen receptor and negative nuclear staining for thyroid transcription factor-1.

isolated pulmonary metastasis was 54 months as opposed to 10 months in patients with synchronised pulmonary recurrence (metastasis to other organs as well). ${ }^{2}$

Contributors MPR contributed to the manuscript (case description and learning points). MSR assisted with writing case description. DRN revised the manuscript. EBM provided description on the pathology slides.

Competing interests None declared.

\section{Learning points}

- Endometrial cancer in stage IB has the propensity to recur even after surgical excision and brachytherapy.

- Solitary lung lesion in a patient with previously treated endometrial carcinoma should be biopsied to rule out pulmonary metastasis.

- Positive nuclear staining for oestrogen receptors and negative nuclear staining for thyroid transcription factor-1 can differentiate primary lung adenocarcinoma from endometrial carcinoma.

- Patients with isolated pulmonary metastasis have an overall survival of 54 months.

\section{Patient consent Obtained.}

Provenance and peer review Not commissioned; externally peer reviewed. (C) BMJ Publishing Group Ltd (unless otherwise stated in the text of the article) 2018. All rights reserved. No commercial use is permitted unless otherwise expressly granted.

\section{REFERENCES}

1 Otsuka I, Ono I, Akamatsu H, et al. Pulmonary metastasis from endometrial carcinoma. Int J Gynecol Cancer 2002;12:208-13.

2 Turan T, Ureyen I, Karalok A, et al. Pulmonary recurrence in patients with endometrial cancer. J Chin Med Assoc 2016;79:212-20.

3 Jiang W, Chen J, Tao X, et al. Possible risk factors of pulmonary metastases in patients with international federation of gynecology and obstetrics stage I endometrioid-type endometrial cancer. Int J Gynecol Cancer 2017:27:1206-15.

Copyright 2017 BMJ Publishing Group. All rights reserved. For permission to reuse any of this content visit

http://group.bmj.com/group/rights-licensing/permissions.

BMJ Case Report Fellows may re-use this article for personal use and teaching without any further permission.

Become a Fellow of BMJ Case Reports today and you can:

- Submit as many cases as you like

- Enjoy fast sympathetic peer review and rapid publication of accepted articles

- Access all the published articles

Re-use any of the published material for personal use and teaching without further permission

For information on Institutional Fellowships contact consortiasales@bmjgroup.com

Visit casereports.bmj.com for more articles like this and to become a Fellow 